\title{
Where is Vote Buying Effective? Evidence from a List Experiment in Kenya
}

August 13, 2016

(C) 2016. This manuscript version is made available under the Elsevier user license 


\begin{abstract}
Vote buying is common in democracies around the world. Yet relatively little is known about the conditions in which vote buying is an effective campaign strategy, in part because vote buying is challenging to measure. This paper examines the local economic and social conditions in which vote buying influences the behavior of voters in Kenya. I combine data from a nationally representative list experiment conducted after Kenya's 2007 elections with highly disaggegrated census data about local economic and social conditions. While 7 percent report that vote buying influenced their vote when asked directly, the list experiment finds that 23 percent were influenced. I find mixed evidence and statistically weak evidence that vote buying is more effective in the local areas where parties should be best able to monitor voters. Vote buying is, however, most effective where voters lack access to information about politics. I discuss the implications of the results for literatures on vote buying, clientelism, and electoral accountability.
\end{abstract}


Politicians attempt to exchange money for votes in many democracies around the world. ${ }^{1}$ Yet, despite its prevalence, empirical evidence on whether vote buying is an effective campaign strategy is mixed and relatively scarce. This paper contributes by examining the local social and economic conditions in which vote buying is an effective campaign strategy. Under what conditions does vote buying influence the voting decisions of voters?

This question has direct implications for democratic accountability, representation, and the quality of governance. When politicians and parties can win votes with cash handouts at election time, rather than by performing well while in office, the accountability relationship between voters and their representatives breaks down. In the worst instances, vote buying may produce a form of "perverse accountability," whereby vote-buying political parties hold voters accountable for their voting behavior (Stokes, 2005). Moreover, vote buying is likely to undermine the political representation of poor voters who are often the targets of vote-buying efforts (Stokes, 2007). As a result, vote buying may diminish the incentives of governments to be responsive to the needs of those living in poverty (Khemani, 2012).

While this question is of clear importance and relevance to debates about the drivers of weak accountability in democratic contexts, data limitations have made it a difficult one to address. Indeed vote buying is often illegal and generally in violation of well recognized norms about how both politicians and voters should behave in a democratic society. Given the sensitivity of vote buying, survey and interview questions designed to measure its effectiveness are likely to be influenced by "social desirability bias" (Bradburn et al., 1978; DeMaio, 1984; Gonzalez-Ocantos et al., 2012; Tourangeau and Yan, 2007). ${ }^{2}$ This poses a challenge to the measurement of vote buy-

\footnotetext{
${ }^{1}$ Vote buying has been documented in contemporary Latin American countrries such as Argentina (Auyero, 2001; Brusco et al., 2004), Mexico (Magaloni, 2006), and Nicaragua (Gonzalez-Ocantos et al., 2012); Middle Easern countries such as Egypt (Blaydes, 2010), Jordan (Lust-Okar, 2006), and Lebanon (Corstange, 2010); in Asian countries such as the Philippines (Khemani, 2012) and Taiwan (Wang and Kurzman, 2007); and in African countries such as Benin (Banegas, 2002), Ghana Nigeria (Bratton, 2008), São Tomé and Príncipe (Vicente, 2014), and Uganda (ConroyKrutz and Logan, 2012).

${ }^{2}$ Social desirability bias occurs when survey or interview respondents provide a socially acceptable, rather than a truthful, answer to questions about sensitive attitudes and behaviors.
} 
ing and, because response bias may be concentrated among specific sub-groups of the population (Gonzalez-Ocantos et al., 2012), to the making of valid inferences about the causes and correlates of vote-buying's effectiveness.

This paper advances the literature on vote buying by examining the local economic and social conditions in which vote buying influences the behavior of voters in Kenya, an east African country where vote buying is widespread. To address the challenge of social desirability bias, I analyze data from a nationally representative survey list experiment conducted after Kenya's 2007 elections. As I detail below, the list experiment provides a method for indirectly eliciting truthful responses to sensitive survey questions (Corstange, 2010; Gonzalez-Ocantos et al., 2012; Kuklinski et al., 1997; Weghorst, 2010). ${ }^{3}$ To investigate the conditions in which vote buying is effective in influencing voters, I combine the list experimental data with highly disaggregated data from the Kenyan census. More specifically, I map survey respondents into their administrative sub-locations - local level units that typically are home to around 700-800 households ${ }^{4}$ - and use official census data to measure a number of local economic and social conditions that may relate to the effectiveness of vote buying.

The analysis produces several key results. First, while about 7 percent of respondents report that vote buying influenced their voting decisions in the 2007 elections when asked directly, the list experimental estimate suggests that about 23 percent of voters were influenced by vote buying. This degree of response bias is consistent with prior work on this topic (Corstange, 2010; GonzalezOcantos et al., 2012). Second, I find mixed and statistically weak evidence that vote buying is more effective in the types of conditions where political parties are likely to be best able to monitor voters and infer their voting behavior. On the one hand, the evidence suggests that the effectiveness of vote buying increases with population density, and population dense areas may be those where

\footnotetext{
${ }^{3}$ Prior research on vote buying has also sought to reduce response bias by asking voters about what "others like them" would do if they were to be approached with a vote-buying offer during a campaign (defect, comply, or refuse). See, for example, Bratton (2008) on Nigeria, and Conroy-Krutz and Logan (2012) on Uganda.

${ }^{4}$ As of the 2009 census, there were 7,150 sub-locations in Kenya. My sample includes 233 of them, which were randomly selected to produce a nationally representative sample (more details on the sampling and data below).
} 
parties are better able to efficiently monitor voters. On the other hand, vote buying is found to be more effective in rural areas, where party monitoring capacity is generally very low both in Kenya and elsewhere in sub-Saharan Africa (Bratton, 2008; Ferree and Long, ming). Neither of these results, however, are statistically significant. Third, I find that vote buying is more effective in less competitive electoral constituencies, Finally, I find that vote buying is more effective in contexts where voters lack sources of information about politics, even after controlling for a range of other indicators of wealth, education, and under-development. ${ }^{5}$

These results contribute to several related literatures. First, the results are consistent with theoretical arguments that emphasize the role of vote buying in conveying information to voters (e.g. Muñoz Chirinos, 2014; Kramon, 2016), providing novel evidence that is consistent with such approaches. Second, the results contribute to the literature on information and accountability, providing evidence that information access reduces the electoral influence of vote buying. This result adds to a small empirical literature examining the link between information and vote buying (Fujiwara and Wantchekon, 2013; Gottlieb, 2016; Keefer and Khemani, 2014). Third, the paper contributes to the methodological literature on the measurement of vote buying and other sensitive political topics. As in Corstange (2012) and Gonzalez-Ocantos et al. (2012), I provide evidence of substantial response bias in a direct survey item about the influence of vote buying on voter behavior. In addition, this paper is among the only papers in the literature to test theoretical expectations about vote buying using methods designed to reduce survey response bias (Corstange, 2012; González-Ocantos et al., 2015; Gonzalez-Ocantos et al., 2012). I further elaborate on these contributions in the concluding section.

\footnotetext{
${ }^{5}$ I follow Casey (2015) and Keefer and Khemani (2011) and use access to radio service as a proxy for access to political information (measures discussed further below).
} 


\section{Theoretical Background}

Vote buying involves the "offering [of] particularistic material rewards to individuals or families at election time" (Schaffer, 2007). Vote buying is a form of political clientelism (Stokes et al., 2013), which characterizes instrumental and reciprocal relationships of mutually beneficial exchange between actors of unequal social, economic, and political status (Lemarchand, 1972; Powell, 1970; Scott, 1972).

In contexts where the ballot is secret, vote buying presents a challenge to parties seeking to use it to win votes. In particular, voter privacy presents a contract-enforcement problem for votebuying parties (Stokes, 2005). Since voters cast their ballots in secret, they may accept money or gifts but then subsequently condition their voting decisions on other criteria.

Given this challenge, the effectiveness of vote buying in winning votes cannot be taken for granted; voters may simply accept vote-buying offers and vote on the basis of other criteria. And indeed direct empirical evidence on the electoral effectiveness of vote buying — that is, the extent to which vote-buyers successfully win votes - is relatively scarce and has produced mixed results. ${ }^{6}$ Using a list experiment — which I describe more fully below — Corstange (2012) finds that about half of voters in Lebanon sold their votes during that country's 2009 parliamentary elections. Vicente (2014) experimentally evaluates an anti-vote buying campaign in São Tomé and Príncipe, and finds that reductions in vote buying hurt the voteshare of opposition parties - evidence that vote buying is effective for such parties. Bratton (2008) studies vote buying in Nigeria with survey data and finds that those who were targeted were more likely to support the incumbent party. In Argentina, Brusco et al. (2004) find that vote buying is effective with some, but not all, of those who receive handouts during campaigns. Using survey data, they find that about 16 percent

\footnotetext{
${ }^{6}$ Some analyses study survey questions designed to measure how frequent vote-buying attempts are during elections. For example, Gonzalez-Ocantos et al. (2012) analyze a list experiment in Nicaragua to determine how many voters received a gift or a favor from a party. While this is important information, it does not speak directly to the question of vote buying's effectiveness in winning votes. The effectiveness of the strategy cannot be directly inferred from its prevalence.
} 
of those who received handouts report that the gift influenced their vote. This figure rises to 24 percent among supporters of the Peronist party.

Other research challenges the notion that vote buying is an effective vote-winning strategy. Conroy-Krutz and Logan (2012) analyze vote buying during Uganda's 2011 elections, a campaign in which vote buying was extremely widespread, and conclude that it had no impact on election outcomes. Lindberg and Morrison (2008) and Lindberg (2013) conclude that while vote buying is common in Ghana, voters condition their votes on factors other than clientelism. Others emphasize, importantly, that parties may not even intend to buy votes when they distribute handouts during campaigns. For example, parties may instead distribute gifts to mobilize the voter turnout of their known supporters — "turnout buying" (Nichter, 2008) — or to convince voters to abstain from voting altogether — "abstention buying” (Cox and Kousser, 1981; Gans Morse et al., 2014). These strategies avoid the commitment problem described above, as voter turnout is easily observable.

This paper builds on this empirical literature to examine the social and economic conditions in which vote buying is an effective campaign strategy. I address three categories of explanations, which I discuss in turn.

The first is poverty. Vote buying is prevalent in low-income democracies and there is clear empirical evidence that poor voters are most likely to be targeted by vote-buying parties (Brusco et al., 2004; Jensen and Justesen, 2014). There are a number of reasons why vote buying might be most effective in conditions where voters are living in poverty. First, the marginal benefit of a small material transfer is larger for the poor than it is for the wealthy (Stokes et al., 2013). That is, the types of goods that tend to be distributed during elections are simply more valuable to the poor, and so they may be more responsive to them. Second, the poor may be more risk averse (Stokes et al., 2013). Thus, they may prefer the certainty of up-front transfers ahead of elections, even if they are small, to the uncertain returns of programs and policies that parties might promise during campaigns. Finally, the poor may also be more vulnerable and susceptible to attempts of political parties to violate the secrecy of their ballots. As a result, parties may in some contexts find it easier 
to enforce vote-buying contracts in poor communities.

H1: Vote buying will be more effective where voters are living in poverty.

While poverty is important, it is unlikely to be sufficient to fully explain variation in the extent to which vote buying is electorally effective. For example, the literature highlights that the capacity of parties to monitor voters is also often of central importance (Lehoucq, 2007). Historically, vote buying flourished in contexts where ballot secrecy was not formally protected and parties were able to directly observe how voters cast their ballots (Lehoucq, 2007). Where ballot secrecy is protected, parties have often sought to buy votes in contexts where they can monitor voters despite the secret ballot (Gans Morse et al., 2014). For example, vote buying has been common where political parties are organized as political machines. Because political machines are organizations that are socially embedded and which develop personal relationships with voters, they can reasonably infer vote choices and enforce vote-buying contracts (Brusco et al., 2004; Scott, 1969; Stokes, 2005). In addition, small close-knit communities, where everyones knows one another, also facilitate the kind of voter monitoring required to enforce vote-buying transactions (Brusco et al., 2004; Scott, 1969; Stokes, 2005).

H2: Vote buying will be more effective where parties are able to monitor voters.

Access to information about politics may also influence the extent to which vote buying is a persuasive campaign strategy. In their review of the small experimental literature on clientelism and vote buying in Africa, Vicente and Wantchekon (2009) conclude that access to information may limit the electoral effectiveness of vote buying and clientelist strategies more broadly. There are a number of inter-related reasons why voter access to information may be consequential. First, where voters lack access to credible information about the policy performance of incumbents and the policy proposals of competing candidates, they will be more likely to weight clientelistic considerations more heavily when deciding how to vote, since this dimension is observable to them. 
According to this logic, increasing access to credible information should diminish the influence of vote buying on vote choice (Fujiwara and Wantchekon, 2013).

Access to information may also be consequential because vote buying itself serves an informational function. Kramon (2016), for example, provides evidence that voters in Kenya are responsive to vote buying because they interpret the allocation of electoral handouts as a signal about the electoral viability of candidates and about their ability to provide targeted goods in the future. Similarly, Muñoz Chirinos (2014) argues that parties in Peru engage in vote buying to enhance perceptions of their electoral viability. Related arguments from the African politics literature emphasize the symbolic value of vote buying, which may be understood by voters as reparations for past injustice (Schaffer and Schedler, 2007), as a way to recoup funds that corrupt politicians have stolen while in office (Banegas, 1998), as an informal tax refund (Lindberg, 2003), or as a mechanism that allows political elites to socially legitimize the wealth that they accrue while in office (Nugent, 2007). In each of these formulations, the act of giving out money conveys political and social information to voters that influences their preferences over competing candidates. If voters have access to other sources of information about politicians, the information conveyed by vote buying should diminish in its importance. ${ }^{7}$

Access to information may also be relevant because it drives up the price of vote buying for competing candidates. If, for example, voters are aware that the incumbent has performed poorly while in office — or engaged in corruption, and so on - they will likely require greater compensation by the incumbent in order to change their vote relative to a situation in which voters are uncertain about the incumbent's performance (Gottlieb, 2016). In the short term, the impact of information would thus likely decrease the prevalence of vote buying (assuming a fixed budget), reducing the overall proportion of voters that are targeted by vote buyers.

\footnotetext{
${ }^{7}$ This logic relates to some arguments in the literature about ethnic-based voting. Some argue that ethnicity acts as an informational shortcut that allows voters to evaluate competing candidates in the absence of other sources of political information (or because gathering such information is costly in time and cognitive effort) (Ferree, 2006; Conroy-Krutz, 2012). Increasing voter access to information may thus diminish the role of ethnicity in influencing voting decisions (Conroy-Krutz, 2012).
} 
H3: Vote buying will be more effective where voters lack access to other sources of information about politics.

Finally, electoral competition may also condition the impact of vote buying. Most clearly, electoral competition creates incentives for parties to engage in vote buying (Lehoucq, 2007), and so vote buying is likely to be more prevalent in areas where electoral competition is most intense. The potential effect of electoral competition on vote buying effectiveness is, however, less clear. On the one hand, we might expect parties to invest more in the ability to effectively vote buy in contexts where that vote buying would have a greater chance of impacting the outcome (in competitive contexts).

H4a: Vote buying will be more effective in electorally competiive areas.

On the other hand, the demands of electoral competition may drive those seeking to buy votes to be less discriminating in terms of who they target with vote-buying offers (Corstange, 2010), leading them to target voters that may be less likely to be influenced. Electoral competition may also drive multiple parties to engage in vote buying, potentially dampening its impact, and indeed evidence from the Afrobarometer shows that many voters in Kenya and elsewhere in Africa receive votebuying offers from multiple parties (Guardado and Wantchekon, 2013). For these reasons, electoral competition may limit the electoral effectiveness of vote buying.

H4b: Vote buying will be more effective in less electorally competiive areas.

While electoral competition may have direct effects, it may also condition the impact of other factors. In particular, electoral competition may be consequential for the impact of access to sources of information. For example, in areas of intense partisan competition, voters are likely to be exposed to information about politics by members and supporters of competing parties. In areas dominated by a single party or candidate, on the other hand, these alternative sources of information are likely to be less prevalent. Thus, the impact of access to information on vote buying 
effectiveness may be most pronounced in non-competitive electoral environments.

H5: The impact of access to information will be greater in electorally non-competitive areas.

\section{Context}

I evaluate these hypotheses with data gathered in Kenya, an east African nation with a population of about 40 million. As in most African countries that were colonized by the British, candidates for president contest in a single nationwide district — though they are required to win a minimum threshold of votes from different regions of the country - while candidates for parliament compete in single-member districts with plurality rule elections.

Kenya has held regular multiparty elections since a transition from single-party rule in the 1990s. Vote buying has played a central role in each of these campaigns. Data gathered by the Coalition for Accountable Political Finance in Kenya suggest that vote buying — cash handouts to voters - represents about 40 percent of the average parliamentary candidate's campaign budget, which is by far the largest budget item (Coalition for Accountable Political Finance, 2008). Candidates and their agents distribute these handouts to voters in a range of settings, including at impromptu stops on the campaign trail, during meetings with civic and trade organizations, and at large campaign rallies. For example, candidates in Kenya often organize meetings with local trade groups - such as groups of fisherman or taxi drivers - or civic organizations - such as student, women's, or sports associations - and it is common for candidates to hand out cash to the members of these organizations at such meetings.

Vote buying at campaign rallies is also common. A set of videos released by the Kenyan Human Rights Commission ahead of the 2013 elections documents how vote buying often works during rallies. ${ }^{8}$ One of the videos documents a campaign rally held by James Ongware, a candidate for governor of Western Kenya's Kisii County. The video shows Ongware's campaign agents

\footnotetext{
${ }^{8}$ see http://www.aljazeera.com/news/africa/2013/03/201331141512539677.html, last accessed August 12, 2016
} 
organizing potential voters at the rally into lines for men, women, and youth and then handing out money to those in the line in a relatively orderly fashion. This form of organized vote buying at campaign rallies is common in Kenya. The other video shows a campaign rally held by Ferdinand Waititu, who in 2013 was running for governor of Nairobi county. In that video, Waititu personally hands out money to those in the crowd.

Survey data confirm that vote buying is common in Kenya. According to data collected by the Afrobarometer, around 40 percent of adults were offered "a bribe or gift in exchange for their vote" during the country's 2002 elections. In the survey data described below, about 22 percent of respondents admit that they received money from a party or politician during the 2007 campaign.

The goal of this paper is to determine whether and where these investments in vote buying are effective. The data contain information on vote buying Kenya's 2007 elections. The 2007 presidential election featured an intense and hotly contested race between Mwai Kibaki, the incumbent and candidate of the Party of National Unity (PNU) coalition, and Raila Odinga, the leader of the opposition Orange Democratic Movement (ODM). Early voting returns after the election suggested a victory for Odinga, leading ODM to declare victory. When the Electoral Commission announced the official results, however, they indicated a narrow victory for Kibaki, leading Odinga and his allies to make allegations of electoral fraud. After Kibaki was hastily sworn in as president, violence broke out across the country. Over 1,000 people were killed and hundreds of thousands more were displaced as a result of the post-election violence. While this tragic episode is not the focus of this paper, I return to it in the conclusion when I discuss the potential contributions of vote buying to the outbreak of violence.

\section{Research Design and Data}

Existing research documents that social desirability bias poses a serious challenge to measurement of vote buying, as well as to inference about its causes and consequences. In Nicaragua, Gonzalez- 
Ocantos et al. (2012) estimate that direct survey items about vote buying under-estimate the true prevalence by about 22 percentage points. In Lebanon, Corstange (2010) estimates that twice as many people exchanged their vote for money than are willing to admit to doing so when responding to a direct survey question. ${ }^{9}$ Response bias thus poses a clear challenge to the measurement of vote buying.

Because response bias may be concentrated among certain sub-groups of the population, social desirability bias also poses a threat to inference about the correlates of vote buying and its effectiveness. Indeed Gonzalez-Ocantos et al. (2012) find that response bias is not randomly distributed across the population in Nicaragua. They show that certain sub-groups are more likely to provide socially desirable responses. To understand why this could be problematic for inference, consider a simple hypothetical example where both men and women sell their vote at the same rate. Now imagine that women are more honest on the survey than men, which would make it seem as if women are much more likely to sell their votes. The problem, of course, is that this difference is driven entirely by sub-group variation in response bias, rather than any real systematic differences in the propensity of the groups to sell their votes. It is for this reason that reducing response bias is essential to producing valid inferences about vote buying.

\subsection{Measuring the Electoral Effectiveness of Vote Buying}

This study aims to identify the local conditions in which vote buying influences voting decisions. I thus require a measure of effective vote buying, which is important to distinguish from two other related but distinct outcomes and concepts. First, there are vote buying offers: that is, attempts by political parties or politicians to buy a vote. Vote buying offers are distinct from effective vote buying because many voters may simply refuse to accept an offer when it is made (Bratton, 2008). Second, there are instances where the offer is accepted but voters choose to condition their votes on

\footnotetext{
${ }^{9}$ This challenge is not unique to surveys. It can also pose problems for qualitative methodologies, as interview respondents and focus group participants may also alter their responses in socially acceptable ways.
} 
other criteria: that is, voters might defect from a vote-buying arrangement (Bratton, 2008; ConroyKrutz and Logan, 2012; Stokes, 2005). Defection may be especially prevalent in contexts where parties have difficulty monitoring voters, as is the case in parts of Africa (van de Walle, 2007). In such instances, vote buying is clearly ineffective. Given these distinctions, this study requires a measure that captures whether vote buying influenced the vote, not whether vote-buying offers were made or accepted. I thus designed the survey to measure whether respondents voters for a party of politician because they gave them money during the campaign.

To address the response bias challenge, I conducted a survey and survey list experiment with a nationally representative sample of 2,000 Kenyans. ${ }^{10}$ The list experiment, also known as the itemcount technique, has emerged as a popular method for indirectly eliciting truthful responses to sensitive survey questions. Kuklinski et al. (1997), for example, use the technique to study racial attitudes and Weghorst (2010) uses it to study support for political violence. Gonzalez-Ocantos et al. (2012) and Corstange (2010) use the list experiment to demonstrate the bias in direct survey items about electoral clientelism in Nicaragua and Lebanon.

The list experiment procedure is as follows: First, list experiment participants are randomly assigned into one treatment and one control group. Control group respondents are given a list of $J$ non-sensitive attitudes or activities, about which we would not expect response bias (in this experiment, $J=4)$. Treatment group respondents are given a list of $J+1$ items - the same nonsensitive items along with the sensitive item of interest. All respondents are instructed to tell the enumerator how many of the items apply to them (0-4 or $0-5)$. Respondents are told explicitly not to identify which items are true for them and only to indicate how many of the items are true for them. As respondents are only required to state a number, rather than to answer any questions directly, the assumption is that participants will be more truthful with respect to the sensitive survey

\footnotetext{
${ }^{10}$ I designed the survey items and implemented them with the survey firm Synovate as part of their quarterly Social, Political, Economic, and Cultural Survey (SPEC). Synovate is one of the most reputable survey firms in Kenya, and the public opinion data collected by their SPEC surveys are referenced frequently by news and other sources. The survey was conducted in Kiswahili by trained enumerators. The SPEC collects a sample of respondents from all 8 of Kenya's provinces.
} 
item. For example, if a participant in the treatment list agrees with the sensitive statement and two of the non-sensitive items, they will report " 3 " to the enumerator. From this response, there is no reason to believe that the enumerator can deduce the participant's response with respect to the sensitive item.

The list experiment estimates depend on two assumptions. First, we assume that participants are in fact truthful with respect to the sensitive item (Blair and Imai, 2012). Second, we assume that the inclusion of the sensitive item on the treatment list does not impact how treatment list participants respond to the control items (Blair and Imai, 2012). If the latter assumption holds, random assignment to treatment and control groups implies that on average the number of applicable non-sensitive items will be the same in treatment and control groups. If both assumptions are not violated, the simple difference-of-means between treatment and control groups provides an unbiased estimate of the proportion of the population to whom the sensitive item applies (e.g. Blair and Imai, 2012; Glynn, 2013).

The survey was conducted in June $2010 .{ }^{11}$ The sample was stratified by province and by urban/rural location. Sampling points were selected through multi-stage cluster sampling. Using the 2009 census administrative boundaries, 55 of 69 districts were selected in the first stage. Sampling points - defined as the sub-location, the smallest administrative unit for which census data are available - were then selected using probability-proportion-to-size sampling, using data from the 2009 census. $^{12}$

\footnotetext{
${ }^{11}$ The survey was thus conducted about 30 months following the elections. While one might be concerned about recall issues given the length of time between the election and the survey, recall biases would need to be correlated with the key independent variables of interest in order to bias the inferences of the study. In addition, survey questions about vote buying tend to be highly sensitive in the period immediately following elections, a sensitivity that undoubtedly would have been amplified by the violence that followed the elections under study. The questions about vote buying, and the election in general, would have been less sensitive by 2010. I also note that Afrobarometer's Round 5 survey in Kenya was conducted in 2011, and that survey asked vote buying and other election related questions about the 2007 elections. Afrobarometer's Round 3 survey was conducted in 2005 and that survey asked vote buying and other election related questions about the 2002 elections.

${ }^{12}$ After arriving at the selected sampling points, interviewers selected respondents in the following manner. First, interviewers identified a landmark at the sampling site (church, school, shop, and so on). Starting from the landmark, the interviewers used the summation method to select the first household to be sampled. This involves summing the last two digits of the date to determine the first household to be sampled. If the interviews took place on the 27 th, the interviewers would have selected the 9 th household on the left from the landmark. After the first household, the
} 
The prompt in the list experiment was as follows:

Election campaigns are a busy time in our country. I am going to read you a list of some of things that people have told us happened to them during the 2007 campaign. I am going to read you the whole list, and then I want you to tell me how many of the different things happened to you. Please do not tell me which of the things happened to you, just how many. If you would like me to repeat the list, I will do so.

The sensitive item on the list experiment was as follows:

You voted for a party or politician because they gave you money during the campaign.

Note that this sensitive item is designed explicitly to capture effective vote buying, rather than offers or the receipt of gifts, which is consistent with the objectives of this paper.

As a comparison, I conducted a parallel list experiment on vote buying prevalence. While not the main focus of this paper, I present these results as well for comparison. In what follows, I refer to this as the vote buying prevalence list experiment. The sensitive item in this list experiment was as follows.

- You received money from a party or politician.

Both list experiments use the same control group. Thus, each participant in the survey was randomly assigned to one of three conditions: 1) the vote buying effectiveness treatment list, 2) the vote buying prevalence treatment list, and 3) the control list. I present the main results on vote buying prevalence in Appendix D.

interviewers sampled every fourth household on the left. If an interview attempt was unsuccessful, the interviewers continued to the immediate next household. After selecting a household, interviewers enumerated all occupants of the household over 18 years of age and used the serial number on the questionnaire to select the respondent. If the respondent was not home, the interviewer would return to the household three times to find the respondent. If the respondent was not available after the three attempts, another member of the household was substituted in the following manner: on even dates, the person above the original respondent on the household list was chosen and on odd dates the person below was selected. 
The baseline list of non-sensitive items included the following four items:

1. Politicians put up posters or signs in the area where you live.

2. You read the newspaper almost every day to learn about the campaign.

3. You met a politician personally to discuss his or her candidacy.

4. You discussed the campaign with a chief or another traditional leader.

These items were selected because they are relatively simple and related to politics. Respondents were also provided a sheet of paper with the list to help with the aggregation process. Directly after the list experiment was completed, each respondent answered a direct version of the prevalence and influence questions.

\subsection{Explanatory Variables}

To examine the local conditions in which vote buying is likely to be effective, I link each respondent in the survey to the administrative sub-location in which they live. In Kenya, sub-locations are small sub-district administrative units. As of the 2009 census, there were 7,150 sub-locations in Kenya. According to data collected from the 2009 census, the median sub-location has about 3700 residents and 780 households. The most rural sub-locations are home to about 1000 residents and 200 households (the 5th percentile), while more urban sub-locations have a population of around 14000 individuals and 3300 households (95th percentile). The median sub-location is about 15 square kilometers in size and has a population density of about 260 people per square kilometer.

The survey sample includes information from 2000 individuals living in 233 sub-locations. These sub-locations represent the primary sampling unit of the survey and were selected through a procedure designed to produce a nationally representative sample.

To test the study hypotheses, I use data from the 2009 census to construct sub-location level indicators of poverty and wealth, party monitoring capacity, and access to information. I describe 
each in turn:

Measuring Poverty and Wealth Using data from Kenya's 2009 census, I generate a number of indicators that capture different dimensions of poverty and underdevelopment. I measure the share of households in each census sub-location that have electricity and piped water in their home. In the median sub-location in the sample, only 5 percent of households have electricity while the average rate of household electricity is 22 percent of households. In the most remote sublocations, no households have electricity, while in urban areas almost all do. With respect to piped water, 7 percent of households in the median sample sub-location have piped water in their home. The average rate is 20 percent of households. In some sub-locations, no households have piped water, while in the most developed sub-locations about 80 percent do. Additionally, I measure the formal unemployment rate in each sub-location. The average and median sub-location has a formal unemployment rate of about 44 percent. The best off areas have rates of about 15 percent while the poorest areas have formal unemployment rates of about 80 percent. Finally, I measure the proportion of the population in each sub-location with at least a primary education and the proportion with at least a secondary education. On average, about 48 percent of the population in each sub-location has at least a primary education, while about 19 percent have at least a secondary education.

Measuring the Conditions that Facilitate Voter Monitoring. I use two measures to proxy party monitoring capacity. First, I use a measure of population density. Population density is expected to be positively correlated with the ability of parties to monitor voters, since monitoring may be more efficient in population dense areas and population density likely increases the regularity of interactions between vote brokers and potential clients. Second, I compare the effectiveness of vote buying in rural versus urban areas. The literature on African politics highlights that party monitoring and organizational capacity is generally lower in rural areas (Bratton, 2008; Ferree and Long, ming). We would thus expect vote buying to be more effective in urban environments where party monitoring capacity is expected to be higher. 
Measuring Access to Political Information. I follow Casey (2015) and Keefer and Khemani (2011) — both studies that seek to identify the impact of access to political information on political behavior in African settings - and use access to radio service as a proxy for exposure to political information. In Keefer and Khemani (2011), access to the radio is used as a measure of more general exposure to mass media and is used to study how such media exposure relates to local public goods provision. In Casey (2015), access to the radio is used to study how access to political information shapes the likelihood that voters will vote against parties not traditionally associated with their ethnic group. Casey (2015) uses access to radio as a measure of access to information about political candidates, and I do the same in this paper.

Access to radio service is a good proxy for exposure to political information because, in Africa, radio remains the central source of media for the overwhelming majority of the population. Of the almost 23,000 Africans surveyed by the Afrobarometer from during the round of surveys conducted from 2011 to 2012, about 48 percent report that they access news from the radio everyday, while an additional 25 percent get news from the radio a few times a week. In contrast, only 32 percent report accessing news from television sources everyday, and 43 percent report that they never receive news from the television. The same is true of newspapers and the internet. Only 8 percent of all respondents get news from a newspaper everyday, while 61 percent never do. Similarly, only 6 percent receive news from the internet everyday and 80 percent never do. It is clear that, despite the growth of information technology on the continent, the radio remains centrally important to access to political information in Africa.

The patterns in Kenya are comparable to those in the rest of Africa. In the Kenya sample, 68 percent access news from the radio everyday, while 16 percent get news from the radio a few times a week. In contrast, 33 percent get news from the television everyday, 10 percent gets news from the newspaper everyday, and 6 percent access news from the internet everyday. Most Kenyans, however, have no access to these other media. About 40 percent are never exposed to news on the television, 52 percent never get news from the newspaper, and 77 percent never access news on the 
internet.

While Casey (2015) and Keefer and Khemani (2011) use data about radio service signals, I rely on direct measures of access to radio service with data about sub-location radio service coverage collected as part of Kenya's 2009 census. To measure a sub-location's radio coverage, I calculate the share of all households with access to radio service.

Measuring Electoral Competition. To measure electoral competition, I use official parliamentary elections results from the 2007 election. I create a measure of the vote margin between the two candidates receiving the most votes in each constituency. Smaller values of the vote margin thus correspond to higher degrees of electoral competition.

In addition to these variables, the models include controls for female/male, and age.

\subsubsection{Costs and Benefits of the Approach to Measurement}

While many studies of vote buying use individual measures to test hypotheses about the drivers of vote buying's effectiveness, this study relies on community level measures. A disadvantage of this approach is that it involves the use of relatively indirect measures of the key independent variables. It also means that the study is best equipped to address questions about the local conditions in which vote buying is effective, rather than about the specific individual characteristics that are associated with effective vote buying.

Despite these limitations, there are several important advantages of the approach to measurement I adopt. First, the community-level measures are likely less susceptible to potential endogeneity bias than are the corresponding individual level measures. For example, access to information at the community level is likely to be more exogenous than more direct measures of political information access at the individual level. Indeed it is likely that the types of people that choose to access political information are different than people who do not, and people who seek out political news may also be the types of people that are less susceptible to vote buying. The community level measure, while indirect, is less vulnerable to this potential source of endogeneity bias. 
A second advantage of this approach relates most directly to the measure of access to political information. Specifically, an advantage of the community-level measure is that it can capture both direct and indirect effects of media access in a way that an individual measure cannot. This is important because media access can have direct effects (that is, effects on the people that own the radios and listen to political news), as well as indirect effects through social interactions and networks. The community level measure can capture these indirect effects, while a more direct individual measure would not. It is for this reason that several other studies which investigate the impact of information on politics also use similar measures of community-level access to radio (e.g. Keefer and Khemani, 2011).

\subsection{List Experiment Design Checks}

Before turning to the main results, I first evaluate some features of the list experimental design. First, it is important to avoid "floor" and "ceiling" effects when selecting the non-sensitive items (Glynn, 2013). Floor effects refer to a situation in which all of the items would not be applicable to many participants. Ceiling effects refer to the opposite situation in which all of the items would be applicable to many participants. These situations can undermine the indirect nature of the list experiment and can cause suspicion among respondents in the treatment group, which could lead to biased responses. For example, if a respondent in the treatment group responds 5, the enumerator knows with certainty that they agree with the sensitive statement.

Table 1 provides evidence that the design was successful in avoiding floor and ceiling effects. No participants responded 0 to the list experiment question, which suggests that floor effects were not an problem. In addition, only 4 percent of control group participants and 5 percent of treatment group participants responded 4, while only 1 percent of treatment group participants responded 5. Ceiling effects do not appear to have been a problem.

Table 1 about here.

Second, it is important that treatment and control groups do not differ in systematic ways. 
Table 2 provides evidence that treatment and control groups are indeed similar on a number of possible measures, including the age and gender of respondents, urban/rural, population density, and indicators of poverty and underdevelopment.

Table 2 about here.

Finally, it is important to examine evidence of possible "design effects" (Blair and Imai, 2012). Design effects occur when the inclusion of the sensitive item on the treatment list impacts how respondents in the treatment group respond to the non-sensitive items. I follow Blair and Imai's (2012) procedure for examining design effects and do not find evidence to reject the null hypothesis of no design effects. ${ }^{13}$

\section{Results}

\subsection{Difference-of-Means Estimates}

I begin by presenting the results using a simple difference-of-means approach. Table 3 presents these list experimental results in the full sample, as well as in theoretically relevant sub-groups. I present the mean response in control (0-4) and in treatment (0-5) in the first two columns. Column 3 presents the difference, which is the list experimental estimate of the proportion of the population that agree with the statement that they voted for a politician or party because they received money from them. For comparison, the final column presents the estimate produced by the direct survey item on the influence of vote buying. The difference between the list experimental estimate and the direct estimate can be interpreted as an approximation of the amount of response bias in the direct item.

The first row presents the estimates in the full sample. When asked directly, 7 percent of the

\footnotetext{
${ }^{13}$ I use Blair and Imai's (2012) list package in R. The test relies on the fact that, in the absence of design effects, the difference in response between treatment and control groups should not be greater than 1 . The test identifies the magnitude of these differences at each possible response value and determines how likely those differences would be to occur by chance (Blair and Imai, 2012).
} 
sample report that vote buying influenced their vote. By contrast, the list experimental estimate suggests that 23 percent had their vote influenced by vote buying. This result provides evidence that vote buying influenced the voting decisions of a sizable proportion of Kenyans and highlights the extent to which response bias poses a challenge to the measurement of vote buying's effectiveness. Table 3 about here.

The remainder of the table presents the estimates in theoretically relevant sub-groups. Since some of the measures are continuous, I create categories of high and low by separating each variable at the median. In the case of electoral competition, I create three groups capturing high competition (vote margin less than 0.11), medium competition (vote margin between 0.11 and 0.31 ), and low competition (vote margin greater than 0.31). ${ }^{14}$ Rows 2 and 3 suggest that vote buying is more effective in low radio coverage areas (19 percent impacted in high radio coverage versus 31 percent in low). Rows 4-6 suggest that vote buying is more effective in medium and high electoral competition constituencies. Rows 7 and 8 show that vote buying is slightly more effective in areas with less access to household electrification (26 percent in low versus 21 percent in high), which is consistent with the poverty hypothesis.

Rows 4 and 5 show that vote buying has more influence in rural areas (26 percent) versus urban ones (18). Yet vote buying is also substantially more effective in high population density areas (34 percent) versus low population density areas (12 percent). The initial evidence is thus mixed on the voter monitoring hypothesis. Rows 8 and 9 show that vote buying has greater influence where access to radio service is low: 30 percent are influenced where access is low versus 19 percent where access is high. This is preliminary evidence consistent with the hypothesis that access to information conditions the effectiveness of vote buying.

Table 3 also provides evidence about the potential biases in inferences one would make by focusing exclusively on the direct survey question. For example, the data from the direct question would lead us to conclude that women are almost twice as as men likely to have their vote influ-

\footnotetext{
${ }^{14}$ These cutpoints correspond to the $33 \mathrm{rd}$ and 66 th percentiles.
} 
enced by vote buying: 9 percent of women responded yes to the direct question while 5 percent of men did so. The list experiment estimates demonstrate, however, that this inference is driven entirely by the fact that women are more honest than men when responding to the direct question (though there is still response bias among women). In fact, men are actually more likely to be influenced by vote buying than are women. This example highlights the importance of considering response bias when making inferences about vote buying.

\subsection{Multivariate Regression Estimates}

I now turn to a regression framework, which allows us to examine the impact of continuous measures and to determine whether inferences are robust to the inclusion of control variables. I estimate the following basic model using Ordinary Least Squares (following Gonzalez-Ocantos et al., 2012):

$$
Y_{i}=\alpha+\beta_{1} T_{i}+\beta_{2} X_{i}+\beta_{3} T_{i} X_{i}+\varepsilon_{i}
$$

The unit of analysis is the individual survey respondent. $Y_{i}$ represents the count response (0-5) of participant $i$ in the list experiment. $T_{i}$ is a dummy variable that takes a value of 1 if participant $i$ received the treatment list (with the sensitive item), and 0 otherwise. In a model estimated without covariates, $\beta_{1}$ would provide an estimate of the proportion of the sample for whom the sensitive item is true (the equivalent of the simple difference of means estimate presented above). $X_{i}$ is an explanatory variable and $T_{i} X_{i}$ is the interaction between that variable and the treatment indicator. The coefficient of central interest is $\beta_{3}$, which provides an estimate of how much more or less effective of vote buying is as $X$ changes. Because the explanatory variables are measured at the level of the sub-location, I cluster standard errors by sub-location when estimating this model (233 clusters in total). For ease of interpretation, I present the results from the OLS estimator in the main text. In Appendix B, I show that the results are robust to the use of the non-linear least squares 
(NLS) estimator proposed by Blair and Imai (2012).

The results are presented in Table 4. Column 1 presents results from a model that includes indicators of wealth and development. Column 2 includes proxies for monitoring capacity, while columns 3 and 4 include indicators of access to information and electoral competition. None of the coefficients in these models are significant.

Table 4 about here.

Column 4 includes each of the predictors in the same model. Three variables stand out as significant. First, the primary education and electricity variables are significant, but the sign of the coefficients are positive, which suggests that vote buying is more influential in sub-locations where a greater proportion of the population has a primary education and access to electricity. These results are not consistent with Hypothesis 1.

Access to radio service is also significant in the full model. Vote buying is most effective where access to radio service is low, and it diminishes in influence as access to information increases. To facilitate interpretation, Figure 1 presents the results graphically, displaying the predicted values from the model in column 4. The pattern is consistent with Hypothesis 3: vote buying is most influential where voters lack sources of information.

Regarding the other hypotheses, the evidence for the monitoring hypothesis (H2) is mixed and statistically weak. On the one hand, vote buying does become more influential as population density increases, which is consistent with the monitoring hypothesis. Yet vote buying is also more influential in rural areas, where parties in Kenya and elsewhere in Africa tend to have limited monitoring capacity. The results are also most consistent with the hypothesis that vote buying is more influential in non-competitive electoral environments (H4b). Columns 4 and 5 both show that the effectiveness of vote buying increases with the constituency vote margin, although the coefficients are not significant.

Figure 1 about here.

Table 5 presents results of analyses that test the hypothesis that electoral competition might 
condition the impact of the radio coverage variable. As above, I divide the sample into three groups of constituencies: high competition (vote margin less than 0.11 ), medium competition (vote margin between 0.11 and 0.31 ), and low competition (vote margin greater than 0.31 ). As implied by Hypothesis 5, the radio service variable has the largest effect in medium and low competition environments. The magnitude of the coefficient is largest in the medium competition constituencies. These patterns are consistent with the notion that the information environment may be richer in competitive constituencies, thus reducing the extent to which the radio service variable conditions the impact of vote buying.

Taken together, the results are most consistent the notion that access to information conditions the influence of vote buying. One concern with this interpretation is, however, that the radio access variable may be proxying for poverty or under-development. While the fact that the results are robust to the inclusion of a number of controls that capture poverty should help to alleviate this concern, I conduct an additional set of tests by examining the impact of radio access in the subset of sub-locations that are relatively poor (Table 6). Using the education, unemployment, electricity, and piped water measures, I subset the data to include only the bottom quartile of sub-locations for the analysis. I thus conduct the analysis on the subset of sub-locations where less than 41 percent of the population has a primary education, less than 11 percent of the population has a secondary education, more than 54 percent of the population is unemployed, less that 0.5 percent of households have electricity, and less than 0.1 percent of households have piped water. In each model, the results are consistent: vote buying is more effective in areas where radio access is low, even among this subset of poor sub-locations.

Table 6 about here.

In Appendix C, I conduct an additional set of robustness tests in which I restrict the sample to include only those survey respondents who report having received money from a party or politician during the campaign. These tests thus analyze the effectiveness of vote buying, conditional on the respondent having received a vote-buying offer. While these analyses are underpowered 
statistically, the results are qualitatively similar to the results of the main analyses.

\section{Discussion and Conclusion}

This paper has documented substantial vote buying during Kenya's 2007 elections. It also demonstrates significant response bias on a direct survey question designed to determine how effective vote buying is in winning votes. While 8 percent of the sample reports that vote buying influenced their vote when asked directly, the list experimental estimate suggests that between 20 and 25 percent of voters had their vote influenced by vote buying during that election.

Survey and anecdotal evidence suggest that vote buying has been common in all other elections held in Kenya since 1992. The 2007 elections were, however, unique in that large-scale election violence erupted following the announcement of the election result. It is beyond the scope of the data analyzed in this paper to determine whether vote buying influenced the election results or directly contributed to the violence that broke out following the election. Since almost all parties in Kenya engage in vote buying and many voters in the country experience vote-buying offers from multiple parties (Guardado and Wantchekon, 2013), I would speculate that vote buying did not significantly impact the outcome of the national level presidential contest, although it's impact on more local level elections may be more pronounced. It is thus highly unlikely that vote buying contributed directly to the outbreak of violence that followed the 2007 elections. However, because vote buying may help to create the general perception that elections are not conducted fairly or legitimately, the campaign strategy may have contributed to the violence indirectly by helping to foster an environment conducive to election violence. It will be important for future research on vote buying to evaluate the strategy's broader impact on perceptions about the legitimacy and fairness of elections, attitudes about the legitimacy of political violence, and general attitudes about democracy.

While one goal of this paper has been to measure the influence of vote buying, an additional 
goal has been to examine the local conditions in which vote buying is effective using a method — the list experiment — designed to reduce survey response bias. The contribution complements Gonzalez-Ocantos et al. (2012), which uses a list experiment to study the correlates of the incidence of vote buying, ${ }^{15}$ and Corstange (2012), which uses a list experiment to examine the correlates of vote selling in Lebanon. Several results of the analysis stand out. First, the results show that access to information — as proxied by a community's access to radio service — appears to have an influence on the effectiveness of vote buying. The results of the robustness tests presented in Table 6 suggest that this effect is independent from the more general effects of underdevelopment and poverty. This paper thus offers among the first empirical evidence on the association between access to information and the electoral influence of vote buying. Second, the results provide mixed and statistically weak evidence in favor of arguments that emphasize the importance of voter monitoring in facilitating the effectiveness of vote buying. Vote buying becomes more effective as population density increases, but is also more effective in rural areas where party monitoring capacity is generally weak. Third, the results suggest that the influence of vote buying increases as electoral competition goes down, although this result is not statistically strong.

Several limitations of the analysis that must be acknowledged. First, the main independent variables are measured at the community level, while the outcome is measured at the individual level. While there are certain advantages to this approach - namely that the community level measures are likely more exogenous than the individuals ones, as discussed above — this does mean that the study is better suited for tests of hypotheses about the local conditions in which vote buying is effective than it is for tests of hypotheses about the types of individuals that are most influenced by vote buying, given the potential problem of ecological inference (King, 1997). Since many of the key variables in this study are those that we would want to measure at the community level, or that we could only measure at the community level - for example, population density,

\footnotetext{
${ }^{15}$ The list experiment in Gonzalez-Ocantos et al. (2012) is designed to measure whether voter received gifts at election, not whether these gifts were effective in winning votes
} 
urban/rural, and the community's access to information - this issue is mainly a limitation for the analyses of the impact of wealth and poverty. The data available allow us to ask whether vote buying is more or less effective in wealthier versus poorer localities, but not whether vote buying is more or less effective with poorer voters. Second, data limitations have forced me to use relatively rough proxies for some of the main explanatory variables in the analysis. While I follow the existing literature where possible, both the population density and the radio service measures are fairly rough proxies for party monitoring capacity and access to information. It will be important for future research to evaluate these hypothesis with more direct measures. Third, data limitations again have made it difficult to evaluate the expectations of all theories of vote buying. In particular, an important set of argument highlights that social norms of reciprocity are likely to make vote buying effective, even when parties cannot monitor voters (Finan and Schechter, 2012; Greene and Lawson, 2014). Unfortunately, proxy measures for such social norms at the community level in Kenya are not available.

Despite these limitations, the results contribute to several interrelated literatures. First, the results contribute to the empirical literature on vote buying, providing new evidence with which to assess potential explanations for vote buying's effectiveness. The weak evidence on the monitoring hypothesis is in keeping with the observations of a number of scholars who have concluded that a great deal of vote buying in Africa (Bratton, 2008; Kramon, 2016; Lindberg, 2010; Vicente, 2014) and elsewhere (Muñoz Chirinos, 2014; Hicken, 2011; Schneider, 2014) is unmonitored. The results are also consistent with a set of theoretical arguments that emphasize the role of vote buying in conveying information to voters (e.g. Muñoz Chirinos, 2014; Kramon, 2016). This paper also contributes to the literature on information and accountability (e.g. Gottlieb, 2016; Humphreys and Weinstein, 2013; Lieberman et al., 2014), adding to a small but growing body of evidence linking access to information to vote buying and clientelism. For example, Fujiwara and Wantchekon (2013) find that public deliberation about the programmatic policy proposals put forth by political candidates, which was randomly assigned to occur in some communities, reduced the incidence of 
vote buying during an election in Benin. Gottlieb (2016) presents results from a field experiment in Mali which show that access to information drives up the amount of money that voters report that they would require in order to sell their vote. Keefer and Khemani (2014) leverage a natural experiment in Benin to show that access to community radio reduces support for hypothetical clientelist candidates in a vignette experiment. While the advantage of prior studies is their ability to causally identify the impact of access to information — something that I am unable to do with the observational data that I analyze in this paper — the advantage of this study is in its measurement of the electoral influence of vote buying. Rather than measuring the incidence of vote buying (as in Fujiwara and Wantchekon, 2013) or employing hypothetical survey experiments (as in Keefer and Khemani, 2014), I measure the influence of vote buying on the voting behavior of a nationally representative sample of adults using a method, the list experiment, designed to minimize response bias. Finally, while my main objective has been substantive, this paper also makes a methodological contribution. This paper is one of a small handful of empirical studies that seeks to identify the correlates of vote buying's effectiveness using methods designed to reduce response bias (others include Corstange, 2012; Gonzalez-Ocantos et al., 2012; González-Ocantos et al., 2015). I provide further evidence on response bias on survey questions related to vote buying, and I document how such bias can impact inferences about the correlates of vote buying's effectiveness. These findings highlight the importance of taking response bias seriously when attempting to measure and make inferences about sensitive political topics such as vote buying. 


\section{References}

Auyero, J. (2001). Poor people's politics: Peronist survival networks and the legacy of Evita. Durham, NC: Duke University Press.

Banegas, R. (1998). Marchandisation du vote, citoyennete et consolidation democratique au Benin. Politique Africaine 69(1), 75-88.

Banegas, R. (2002). La Democratie a pas de Cameleon. Editions Karthala.

Blair, G. and K. Imai (2012). Staistical analysis of list experiments. Political Analysis 20(1), 47-77.

Blaydes, L. (2010). Elections and Distributive Politics in Mubarak's Egypt. New York: Cambridge University Press.

Bradburn, N., S. Sudman, E. Blair, and C. Stocking (1978). Question threat and response bias. Public Opinion Quarterly 42(2), 221-234.

Bratton, M. (2008). Vote buying and violence in Nigerian election campaigns. Electoral Studies 27(4), 621-632.

Brusco, V., M. Nazareno, and S. C. Stokes (2004). Vote buying in Argentina. Latin American Research Review 39(2), 66-88.

Casey, K. (2015). Crossing party lines: The effects of information on redistributive politics. American Economic Review 105(8), 2410-2448.

Coalition for Accountable Political Finance (2008). Money Factor in Poll Race. Nairobi, Kenya: Coalition for Accountable Political Finance.

Conroy-Krutz, J. (2012). Information and ethnic politics in africa. British Journal of Political Science 43(345-73).

Conroy-Krutz, J. and C. Logan (2012). Museveni and the 2011 Ugandan election: Did the money matter? Journal of Modern African Studies 50(4), 625-655.

Corstange, D. (2010). Vote buying under competition and monopsony: Evidence from a list experiment in Lebanon. Presented at the Annual Meeting of the American Political Science Association.

Corstange, D. (2012). Vote trafficking in lebanon. International Journal of Middle East Studies 44(3), 483-505.

Cox, G. W. and J. M. Kousser (1981). Turnout and rural corruption: New York as a test case. American Journal of Political Science 25(4), 646-663. 
DeMaio, T. (1984). Social desirability and survey measurement: A review. Surveying subjective phenomena 2, 257-281.

Ferree, K. (2006). Explaining South Africa's racial census. Journal of Politics 68(4), 803-815.

Ferree, K. and J. D. Long (forthcoming). Gifts, threats, and perceptions of ballot secrecy in african elections. African Affairs.

Finan, F. and L. Schechter (2012). Vote-buying and reciprocity. Econometrica 80(2), 863-81.

Fujiwara, T. and L. Wantchekon (2013). Can informed public deliberation overcome clientelism? Experimental evidence from Benin. American Economic Journal: Applied Economics.

Gans Morse, J., S. Mazzuca, and S. Nichter (2014). Varieties of clientelism: Machine politics during elections. American Journal of Political Science 58(2), 415-32.

Glynn, A. N. (2013). What can we learn with statistical truth serum? Design and analysis of the list experiment. Public Opinion Quarterly 77(1), 159-72.

Gonzalez-Ocantos, E., C. de Jonge, C. Meléndez, J. Osorio, and D. Nickerson (2012). Vote buying and social desirability bias: Experimental evidence from Nicaragua. American Journal of Political Science 56(1), 202-17.

González-Ocantos, E., C. K. de Jonge, and D. Nickerson (2015). Legitimacy buying: The dynamics of clientelism in the face of legitimacy challenges. Comparative Political Studies 48(9), $1127-1158$.

Gottlieb, J. (2016). Greater expectations: A field experiment to improve accountability in mali. American Journal of Political Science 60(1), 143-57.

Greene, K. and C. Lawson (2014). Making clientelism work: How norms of reciprocity increase voter compliance. Comparative Politics 47(1).

Guardado, J. R. and L. Wantchekon (2013). Do electoral handouts affect voting behavior? Presented at the Annual Meeting of the Midwest Political Science Association.

Hicken, A. (2011). Clientelism. Annual Review of Political Science 14, 289-310.

Humphreys, M. and J. Weinstein (2013). Policing politicians. Unpublished Manuscript.

Jensen, P. S. and M. K. Justesen (2014). Poverty and vote buying: Survey-based evidence from Africa. Electoral Studies2014.

Keefer, P. and S. Khemani (2011). Mass media and public services: The effects of radio access on public education in Benin. World Bank Policy Research Working Paper (5559).

Keefer, P. and S. Khemani (2014). Radio's impact on preferences for patronage benefits. World Bank Policy Research Working Paper 6932. 
Khemani, S. (2012). Buying votes vs. supplying public services: Political incentives to underinvest in pro-poor politics. World Bank Policy Research Working Paper No. WPS 6339.

King, G. (1997). A Solution to the Ecological Inference Problem: Reconstructing Individual Behavior from Aggregate Data. Princeton, NJ: Princeton University Press.

Kramon, E. (2016). Electoral handouts as information: Explaining unmonitored vote buying. World Politics.

Kuklinski, J. H., M. D. Cobb, and M. Gilens (1997). Racial attitudes and the "New South". Journal of Politics 59(2), 323-349.

Lehoucq, F. (2007). When does a market for votes emerge? In F. C. Schaffer (Ed.), Elections for Sale: The Causes and Consequences of Vote Buying, pp. 33-45. London: Lynne Rienner Publishers.

Lemarchand, R. (1972). Political clientelism and ethnicity in tropical Africa: Competing solidarities in nation-building. American Political Science Review 66(1), 68-90.

Lieberman, E. S., D. N. Posner, and L. L. Tsai (2014). Does information lead to more active citizenship? Evidence from an education intervention in rural Kenya. World Development 60, 69-83.

Lindberg, S. I. (2003). It's our time to "chop": Do elections in Africa feed neo-patrimonialism rather than counter-act it? Democratization 10(2), 121-40.

Lindberg, S. I. (2010). What accountability pressures do mps in africa face and how do they respond? Evidence from Ghana. The Journal of Modern African Studies 48(01), 117-142.

Lindberg, S. I. (2013). Have the cake and eat it: The rational voter in Africa. Party Politics 19(6), 945-61.

Lindberg, S. I. and M. K. Morrison (2008). Are African voters really ethnic or clientelistic? Survey evidence from Ghana. Political Science Quarterly 123(1), 95-122.

Lust-Okar, E. (2006). Elections under authoritarianism: Preliminary lessons from Jordan. Democratization $13(3), 456-471$.

Magaloni, B. (2006). Voting for Autocracy: Hegemonic Party Survival and its Demise in Mexico. New York: Cambridge University Press.

Muñoz Chirinos, P. (2014). An informational theory of campaign clientelism: The case of Peru. Comparative Politics 47(1), 79-98.

Nichter, S. (2008). Vote buying or turnout buying? Machine politics and the secret ballot. American Political Science Review 102(01), 19-31. 
Nugent, P. (2007). Banknotes and symbolic capital: Ghana's elections under the fourth republic. In E. G. Basedau, M. and A. Mehler (Eds.), Votes, Money and Violence: Political Parties and Elections in Sub-Saharan Africa. South Africa: University of KwaZulu Natal Press.

Powell, J. D. (1970). Peasant society and clientelist politics. American Political Science Review 64(2), 411-425.

Schaffer, F. C. (Ed.) (2007). Elections for Sale: The Causes and Consequences of Vote Buying. Boulder, Colo: Lynne Rienner Publishers.

Schaffer, F. C. and A. Schedler (2007). What is vote buying? The limits of the market model. In F. C. Schaffer (Ed.), Elections for Sale: The Causes and Consequences of Vote Buying. London: Lynne Rienner Publishers.

Schneider, M. (2014). Does clientelism work? A test of guessability in India. Center for the Advanced Study of India Working Paper Series (14-01).

Scott, J. C. (1969). Corruption, machine politics, and political change. American Political Science Review 63(4), 1142-1158.

Scott, J. C. (1972). Patron-client politics and political change in Southeast Asia. American Political Science Review 66(1), 91-113.

Stokes, S. (2007). Is vote buying undemocratic? In F. C. Schaffer (Ed.), Elections for Sale: The Causes and Consequences of Vote Buying. Lynne Rienner Publishers. London: Lynne Rienner Publishers.

Stokes, S. C. (2005). Perverse accountability: A formal model of machine politics with evidence from Argentina. American Political Science Review 99(03), 315-325.

Stokes, S. C., T. Dunning, M. Nazareno, and V. Brusco (2013). Brokers, Voters, and Clientelism: The Puzzle of Distributive Politics. New York: Cambridge University Press.

Tourangeau, R. and T. Yan (2007). Sensitive questions in surveys. Psychological bulletin 133(5), 859.

van de Walle, N. (2007). Meet the new boss, same as the old boss? The evolution of political clientelism in Africa. In H. Kitschelt and S. I. Wilkinson (Eds.), Patrons, Clients, and Policies: Patterns of Democratic Accountability and Political Competition. New York: Cambridge University Press.

Vicente, P. C. (2014). Is vote buying effective? Evidence from a field experiment in West Africa. Economic Journal.

Vicente, P. C. and L. Wantchekon (2009). Clientelism and vote buying: Lessons from field experiments in African elections. Oxford Review of Economic Policy 25(2), 292. 
Wang, C. S. and C. Kurzman (2007). The logistics: How to buy votes. In F. C. Schaffer (Ed.), Elections for Sale: The Causes and Consequences of Vote Buying., pp. 61-78. London: Lynne Rienner Publishers.

Weghorst, K. R. (2010). Public opinion and the politics of opposition in Sub-Saharan Africa. unpublished $\mathrm{ms}$. 


\section{Tables and Figures}

Table 1: The Distribution of List Experiment Respones in Treatment and Control Groups

\begin{tabular}{lcc|cc} 
& \multicolumn{2}{c}{ Control Group } & \multicolumn{2}{c}{ Treatment Group } \\
\hline Response & Frequency & Percentage & Frequency & Percentage \\
\hline 0 & 0 & $0 \%$ & 0 & $0 \%$ \\
1 & 290 & $47 \%$ & 215 & $38 \%$ \\
2 & 235 & $38 \%$ & 204 & $36 \%$ \\
3 & 72 & $12 \%$ & 113 & $20 \%$ \\
4 & 25 & $4 \%$ & 29 & $5 \%$ \\
5 & 0 & $0 \%$ & 8 & $1 \%$ \\
\hline Total & 622 & & 569 & \\
\hline
\end{tabular}


Table 2: Balance Tests

\begin{tabular}{lcccc}
\hline \hline & Mean Control & Mean Treatment & Difference & P-Value \\
\hline Male & 0.466 & 0.516 & -0.049 & 0.106 \\
Age & 2.418 & 2.479 & -0.061 & 0.361 \\
Rural Sub-Location & 0.623 & 0.645 & -0.023 & 0.443 \\
Share in Sub-Location with Radio Service & 0.721 & 0.722 & -0.000 & 0.974 \\
Population Density (log) & 6.062 & 6.071 & -0.009 & 0.934 \\
Share in Sub-Location with Electricity & 0.224 & 0.217 & 0.007 & 0.696 \\
Share in Sub-Location with Piped Water & 0.197 & 0.199 & -0.001 & 0.935 \\
Share with Primary Education & 0.490 & 0.494 & -0.004 & 0.602 \\
Share with Secondary Education & 0.185 & 0.184 & 0.001 & 0.852 \\
Sub-Location Unemployment Rate & 0.463 & 0.452 & 0.012 & 0.171 \\
Ethno-Linguistic Fractionalization (district) & 0.432 & 0.434 & -0.002 & 0.909 \\
Vote Margin (top two candidates) & 0.257 & 0.258 & -0.001 & 0.960 \\
\hline \hline
\end{tabular}


Table 3: List Experiment Results

\begin{tabular}{|l|l|l|l|l|l|}
\hline & Mean Control & Mean Treatment & List Estimate & p-value & Direct Estimate \\
\hline Full & 1.73 & 1.96 & .23 & 0 & .08 \\
High Electricity & 1.73 & 1.95 & .21 & 0 & .07 \\
Low Electricity & 1.72 & 1.98 & .26 & 0 & .08 \\
High Primary Ed & 1.7 & 2 & .3 & 0 & .06 \\
Low Primary Ed & 1.76 & 1.93 & .17 & .02 & .09 \\
High Secondary Ed & 1.73 & 1.96 & .23 & 0 & .09 \\
Low Secondary Ed & 1.73 & 1.97 & .24 & 0 & .06 \\
High Unemployment & 1.73 & 1.93 & .21 & .01 & .08 \\
Low Unemployment & 1.73 & 2 & .27 & 0 & .07 \\
Urban & 1.72 & 1.91 & .19 & .02 & .08 \\
Rural & 1.74 & 2 & .26 & 0 & .08 \\
High Pop Density & 1.69 & 2.03 & .34 & 0 & .08 \\
Low Pop Density & 1.78 & 1.89 & .11 & .15 & .08 \\
High Radio Coverage & 1.72 & 1.91 & .19 & 0 & .07 \\
Low Radio Coverage & 1.74 & 2.05 & .31 & 0 & .09 \\
High Competition & 1.76 & 2.06 & .29 & 0 & .08 \\
Med Competition & 1.73 & 2.02 & .29 & 0 & .06 \\
Low Competition & 1.69 & 1.79 & .1 & .31 & .09 \\
Men & 1.55 & 1.84 & .29 & 0 & .06 \\
Women & 1.89 & 2.09 & .2 & .01 & .09 \\
\hline
\end{tabular}

The first two columns present the mean response to the list experiment question in treatment and control. The LE estimate is the difference of means and the p-value is from a difference of means test. The final column presents the direct question estimate. 
Table 4: Multivariate Analysis of the List Experiment

Vote Buying Effectiveness

\begin{tabular}{lccccc}
\hline & $(1)$ & $(2)$ & $(3)$ & $(4)$ & $(5)$ \\
VARIABLES & All & All & All & All & All \\
\hline \multirow{2}{*}{ Treatment x Share with Primary Education } & 0.31 & & & & \\
& $(0.44)$ & & & & $1.33^{*}$ \\
Treatment x Electricity & 0.18 & & & & $(0.79)$ \\
& $(0.18)$ & & & & $0.76^{* *}$ \\
Treatment x Unemployed & -0.12 & & & & $0.37)$ \\
& $(0.55)$ & & & & $(0.56)$ \\
Treatment x Population Density (log) & & 0.06 & & & 0.07 \\
& & $(0.04)$ & & & $(0.06)$ \\
Treatment x Rural & & 0.16 & & & 0.23 \\
& & $(0.17)$ & & & \\
Treatment x Radio Service (continuous) & & & -0.23 & & $-1.63 * *$ \\
& & & $(0.37)$ & & $(0.69)$ \\
Treatment x Electoral Competition & & & & 0.36 & 0.35 \\
Treatment x Male & & & & $(0.24)$ & $(0.26)$ \\
& 0.10 & 0.09 & 0.11 & 0.08 & 0.10 \\
Treatment x Age & $(0.11)$ & $(0.11)$ & $(0.11)$ & $(0.11)$ & $(0.11)$ \\
& 0.02 & 0.03 & 0.01 & 0.04 & 0.04 \\
Treatment & $(0.05)$ & $(0.05)$ & $(0.05)$ & $(0.05)$ & $(0.05)$ \\
Constant & 0.00 & -0.35 & 0.32 & -0.00 & -0.23 \\
& $(0.39)$ & $(0.36)$ & $(0.30)$ & $(0.15)$ & $(0.52)$ \\
Observations & $1.87 * * *$ & $1.96 * * *$ & $1.80^{* * *}$ & $1.74 * * *$ & $1.89 * * *$ \\
R-squared & $(0.26)$ & $(0.22)$ & $(0.21)$ & $(0.10)$ & $(0.32)$ \\
\hline
\end{tabular}

Each model is estimated using OLS. Robust standard errors clustered on sub-location (233 clusters) are reported in parantheses. The interaction between the treatment indicator and each variables provides an estimate of that covariate's impact on the likelihood that vote buying is effective. The models also include the main independent variables without the interaction term. For ease of interpretation, they are omitted here. The full results are presented in Table A.1 in Appendix A. 
Table 5: Vote Buying Effectiveness Tests at Different Levels of Electoral Competition

\begin{tabular}{lccc}
\hline & $(1)$ & $(2)$ & $(3)$ \\
& High & Med. & Low \\
VARIABLES & Comp. & Comp. & Comp. \\
\hline \multirow{2}{*}{ Treatment x Radio Service (continuous) } & -0.14 & $-2.64^{* *}$ & -0.81 \\
& $(1.28)$ & $(1.24)$ & $(0.97)$ \\
Treatment x Share with Primary Education & 0.25 & 2.27 & 0.79 \\
& $(1.14)$ & $(1.68)$ & $(1.22)$ \\
Treatment x Electricity & 0.59 & 0.46 & 0.87 \\
& $(0.72)$ & $(0.77)$ & $(0.53)$ \\
Treatment x Unemployed & 0.06 & 1.34 & -1.02 \\
& $(0.73)$ & $(1.23)$ & $(0.62)$ \\
Treatment x Population Density (log) & 0.05 & 0.15 & 0.01 \\
& $(0.10)$ & $(0.12)$ & $(0.06)$ \\
Treatment x Rural & 0.10 & 0.23 & 0.31 \\
Treatment x Male & $(0.37)$ & $(0.34)$ & $(0.21)$ \\
& -0.01 & 0.35 & 0.12 \\
Treatment x Age & $(0.18)$ & $(0.22)$ & $(0.13)$ \\
Treatment & 0.01 & 0.09 & 0.00 \\
& $(0.08)$ & $(0.08)$ & $(0.08)$ \\
Constant & -0.40 & -1.09 & 0.41 \\
& $(0.90)$ & $(1.18)$ & $(0.41)$ \\
Observations & $2.21^{* *}$ & $1.91^{* * *}$ & $2.16^{* * *}$ \\
R-squared & $(0.97)$ & $(0.39)$ & $(0.36)$ \\
& & & \\
& 345 & 373 & 434 \\
& 0.11 & 0.13 & 0.09 \\
\hline
\end{tabular}

Each model is estimated using OLS. Robust standard errors clustered on sub-location are reported in parantheses. The interaction between the treatment indicator and each variables provides an estimate of that covariate's impact on the likelihood that vote buying is effective. The models also include the main independent variables without the interaction term. For ease of interpretation, they are omitted here. Constituencies are defined as high competition if the vote margin in 2007 was less than 11 percentage points, medium competition if the vote margin was between 11 and 31 percentage points, and low competition if the vote margin was greater than 31 percentage points. These cutpoints define the 33rd and 66th percentiles of the margin variable. 


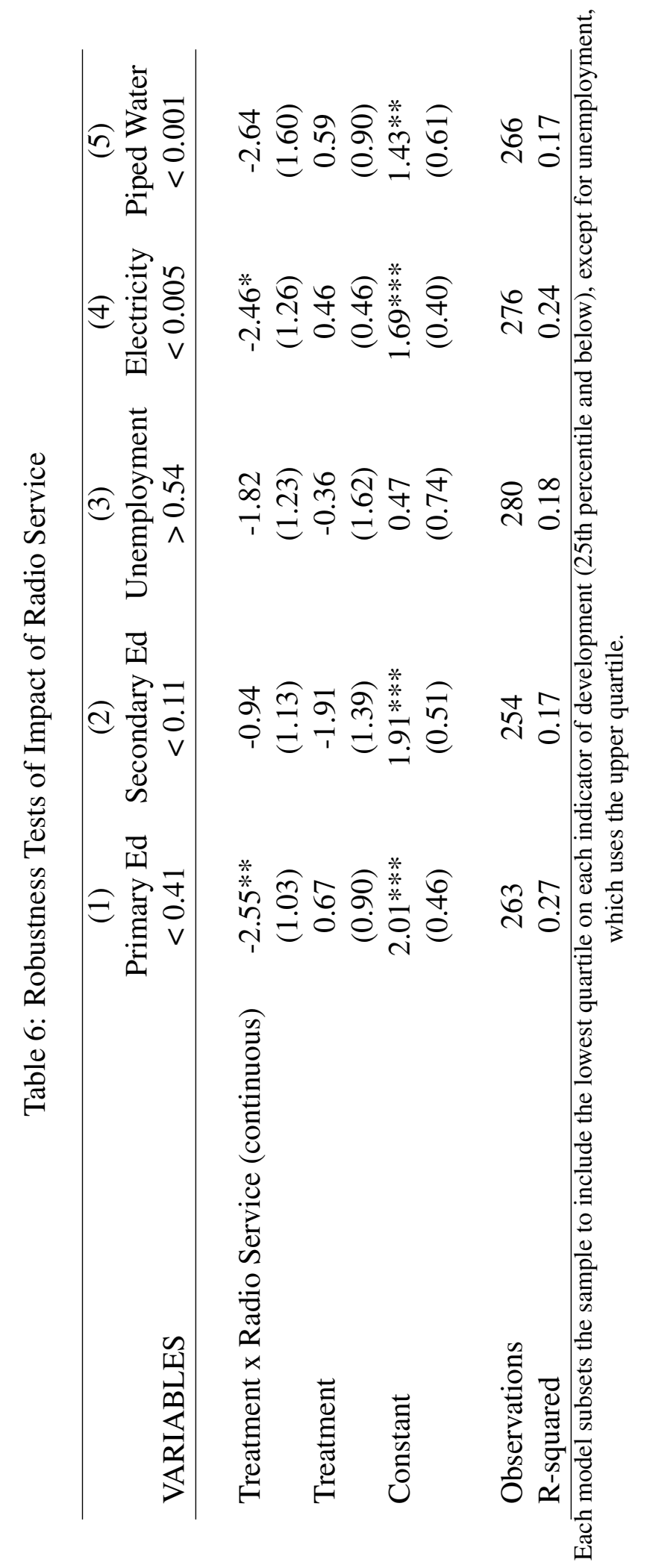


Figure 1: Access to Radio and Vote Buying's Effectiveness

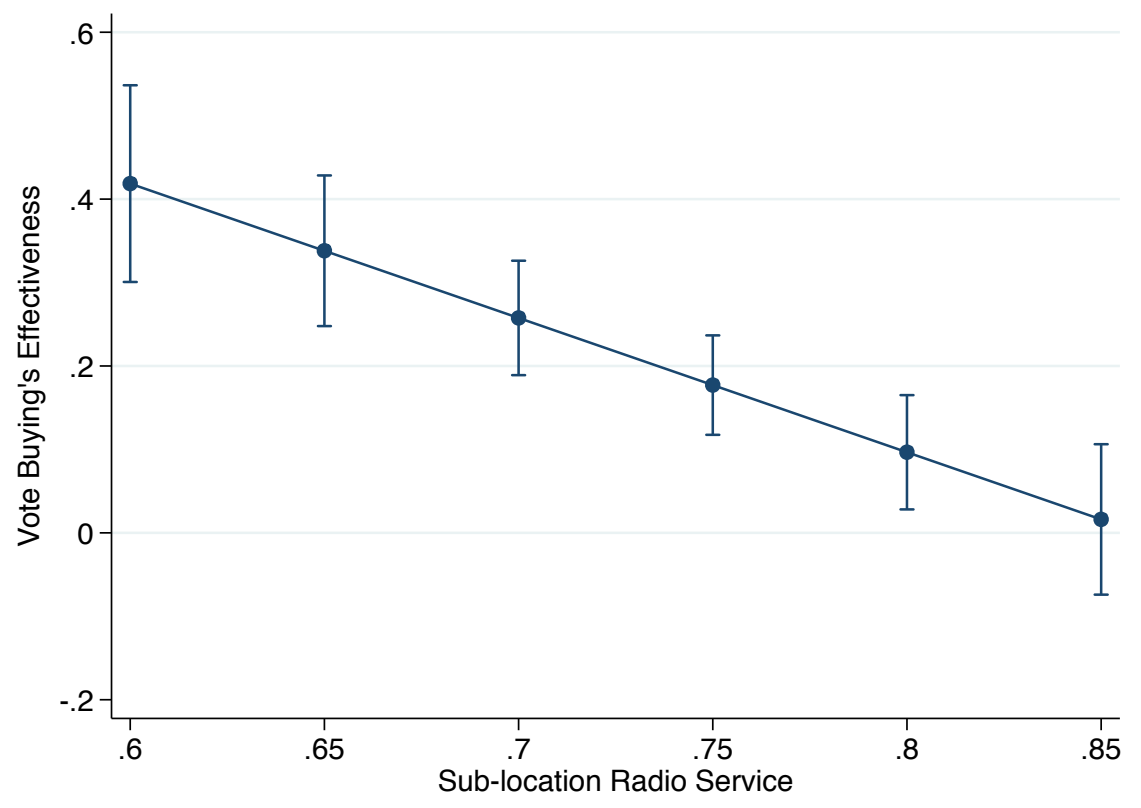

Note: The figure presents predicted values (and one standard error above and below the estimate) generated from the model in column 4 of Table 4 . The $\mathrm{X}$ axis runs along the interquartile range of the radio access variable. 


\section{Appendix}

\section{A Complete OLS Results}


Table A.1: Multivariate Analysis of the List Experiment

Vote Buying Effectiveness

\begin{tabular}{|c|c|c|c|c|c|}
\hline VARIABLES & $\begin{array}{l}\text { (1) } \\
\text { All }\end{array}$ & $\begin{array}{l}\text { (2) } \\
\text { All }\end{array}$ & $\begin{array}{l}\text { (3) } \\
\text { All }\end{array}$ & $\begin{array}{l}\text { (4) } \\
\text { All }\end{array}$ & $\begin{array}{l}\text { (5) } \\
\text { All }\end{array}$ \\
\hline Treatment $\mathrm{x}$ Share with Primary Education & $\begin{array}{c}0.31 \\
(0.44)\end{array}$ & & & & $\begin{array}{l}1.33^{*} \\
(0.79)\end{array}$ \\
\hline Treatment $\mathrm{x}$ Electricity & $\begin{array}{c}0.18 \\
(0.18)\end{array}$ & & & & $\begin{array}{c}0.76 * * \\
(0.37)\end{array}$ \\
\hline Treatment x Unemployed & $\begin{array}{l}-0.12 \\
(0.55)\end{array}$ & & & & $\begin{array}{c}0.03 \\
(0.56)\end{array}$ \\
\hline Treatment x Population Density (log) & & $\begin{array}{c}0.06 \\
(0.04)\end{array}$ & & & $\begin{array}{c}0.07 \\
(0.06)\end{array}$ \\
\hline Treatment $\mathrm{x}$ Rural & & $\begin{array}{c}0.16 \\
(0.17)\end{array}$ & & & $\begin{array}{c}0.23 \\
(0.18)\end{array}$ \\
\hline Treatment x Radio Service (continuous) & & & $\begin{array}{l}-0.23 \\
(0.37)\end{array}$ & & $\begin{array}{c}-1.63 * * \\
(0.69)\end{array}$ \\
\hline Treatment $\mathrm{x}$ Electoral Competition & & & & $\begin{array}{c}0.36 \\
(0.24)\end{array}$ & $\begin{array}{c}0.35 \\
(0.26)\end{array}$ \\
\hline Treatment x Male & $\begin{array}{c}0.10 \\
(0.11)\end{array}$ & $\begin{array}{c}0.09 \\
(0.11)\end{array}$ & $\begin{array}{c}0.11 \\
(0.11)\end{array}$ & $\begin{array}{c}0.08 \\
(0.11)\end{array}$ & $\begin{array}{c}0.10 \\
(0.11)\end{array}$ \\
\hline Treatment x Age & $\begin{array}{c}0.02 \\
(0.05)\end{array}$ & $\begin{array}{c}0.03 \\
(0.05)\end{array}$ & $\begin{array}{c}0.01 \\
(0.05)\end{array}$ & $\begin{array}{c}0.04 \\
(0.05)\end{array}$ & $\begin{array}{c}0.04 \\
(0.05)\end{array}$ \\
\hline Treatment & $\begin{array}{c}0.00 \\
(0.39)\end{array}$ & $\begin{array}{l}-0.35 \\
(0.36)\end{array}$ & $\begin{array}{c}0.32 \\
(0.30)\end{array}$ & $\begin{array}{l}-0.00 \\
(0.15)\end{array}$ & $\begin{array}{l}-0.23 \\
(0.52)\end{array}$ \\
\hline Share with Primary Education & $\begin{array}{l}-0.13 \\
(0.39)\end{array}$ & & & & $\begin{array}{l}-0.36 \\
(0.67)\end{array}$ \\
\hline Share in Sub-Location with Electricity & $\begin{array}{l}-0.13 \\
(0.15)\end{array}$ & & & & $\begin{array}{l}-0.29 \\
(0.35)\end{array}$ \\
\hline Sub-Location Unemployment Rate & $\begin{array}{l}-0.04 \\
(0.32)\end{array}$ & & & & $\begin{array}{c}0.03 \\
(0.32)\end{array}$ \\
\hline Population Density (log) & & & & & $\begin{array}{l}-0.01 \\
(0.04)\end{array}$ \\
\hline Rural Sub-Location & & $\begin{array}{l}-0.06 \\
(0.10)\end{array}$ & & & $\begin{array}{l}-0.11 \\
(0.16)\end{array}$ \\
\hline Share in Sub-Location with Radio Service & & $\begin{array}{l}-0.36 \\
(0.27)\end{array}$ & $\begin{array}{l}-0.08 \\
(0.26)\end{array}$ & & $\begin{array}{c}0.28 \\
(0.48)\end{array}$ \\
\hline Vote Margin (top two candidates) & & $\begin{array}{c}0.36^{* * *} \\
(0.16)\end{array}$ & & $\begin{array}{c}0.16 \\
(0.18)\end{array}$ & $\begin{array}{c}0.18 \\
(0.19)\end{array}$ \\
\hline Male & $\begin{array}{c}-0.33 * * * \\
(0.07)\end{array}$ & $\begin{array}{c}-0.35 * * * \\
(0.07)\end{array}$ & $\begin{array}{c}-0.33 * * * \\
(0.07)\end{array}$ & $\begin{array}{c}-0.34 * * * \\
(0.07)\end{array}$ & $\begin{array}{c}-0.35 * * * \\
(0.07)\end{array}$ \\
\hline Age & $\begin{array}{l}0.06^{*} \\
(0.03)\end{array}$ & $\begin{array}{l}0.06^{*} \\
(0.04)\end{array}$ & $\begin{array}{l}0.06^{*} \\
(0.03)\end{array}$ & $\begin{array}{c}0.05 \\
(0.03)\end{array}$ & $\begin{array}{l}0.06^{*} \\
(0.03)\end{array}$ \\
\hline Constant & $\begin{array}{c}1.87 * * * \\
(0.26)\end{array}$ & $\begin{array}{c}1.96^{* * * *} \\
(0.22)\end{array}$ & $\begin{array}{c}1.80^{* * * *} \\
(0.21)\end{array}$ & $\begin{array}{c}1.74 * * * \\
(0.10)\end{array}$ & $\begin{array}{c}1.89 * * * \\
(0.32)\end{array}$ \\
\hline Observations & 1,152 & 1,078 & 1,152 & 1,110 & 1,078 \\
\hline R-squared & 0.05 & 0.07 & 0.05 & 0.06 & 0.07 \\
\hline
\end{tabular}

Each model is estimated using OLS. Robust standard errors clustered on sub-location (233 clusters) are reported in parantheses. The interaction between the treatment indicator and each variables provides an estimate of that covariate's impact on the likelihood that vote buying is effective. The4lodels also include the main independent variables without the interaction term. 


\section{B Multivariate Results using Non-Linear Least Squares}

Table B.1: Non-Linear Least Squares Estimates (NLS)

\begin{tabular}{lc}
\hline \multicolumn{2}{l}{ Impact on Sensitive Item } \\
Radio Service & -9.82 \\
& $(4.15)$ \\
Electoral Competition & 2.38 \\
& $(1.46)$ \\
Primary Education & 8.43 \\
& $(4.63)$ \\
Electricity & 8.35 \\
& $(3.71)$ \\
Unemployed & 0.88 \\
& $(2.22)$ \\
Population Density & 0.00 \\
& $(0.00)$ \\
Rural & 3.30 \\
& $(1.85)$ \\
Age, $25-34$ & 0.29 \\
& $(0.94)$ \\
Age, 35-44 & 0.23 \\
& $(1.10)$ \\
Age, 45 and above & 0.54 \\
& $(1.02)$ \\
\hline Standard errors in parentheses
\end{tabular}




\section{Effectiveness Results on Subset Who Admit Receiving a Vote- Buying Offter}


Table C.1: Multivariate Analysis of the List Experiment

Vote Buying Effectiveness

Data Only Include Those Who Report Receiving a Vote Buying Offer

\begin{tabular}{lcccc}
\hline & $(1)$ & $(2)$ & $(3)$ & $(4)$ \\
VARIABLES & All & $\begin{array}{c}\text { High } \\
\text { Comp. }\end{array}$ & $\begin{array}{c}\text { Med. } \\
\text { Comp. }\end{array}$ & $\begin{array}{c}\text { Cow } \\
\text { Comp. }\end{array}$ \\
\hline \multirow{2}{*}{ Treatment x Radio Service (continuous) } & -1.78 & -4.32 & -3.84 & -1.41 \\
& $(1.60)$ & $(3.20)$ & $(3.31)$ & $(2.63)$ \\
Treatment x Electoral Competition & -0.42 & & & \\
Treatment x Share with Primary Education & $(0.56)$ & & & \\
& 1.71 & 4.45 & 0.91 & 2.01 \\
Treatment x Electricity & $(2.03)$ & $(2.85)$ & $(7.97)$ & $(3.75)$ \\
& 0.97 & $3.98 * * *$ & -1.38 & 1.44 \\
Treatment x Unemployed & $(0.88)$ & $(1.15)$ & $(3.40)$ & $(1.91)$ \\
Treatment x Population Density (log) & 0.24 & -1.59 & -1.36 & 1.33 \\
Treatment x Rural & $(0.82)$ & $(1.12)$ & $(1.56)$ & $(1.54)$ \\
Treatment x Male & -0.00 & -0.22 & $0.50 *$ & -0.13 \\
Treatment x Age & $(0.12)$ & $(0.18)$ & $(0.28)$ & $(0.19)$ \\
Treatment & 0.21 & $1.15 * *$ & 0.45 & -0.41 \\
Constant & $(0.36)$ & $(0.51)$ & $(0.60)$ & $(0.68)$ \\
R-squared & 0.05 & -0.22 & -0.04 & 0.01 \\
& $(0.21)$ & $(0.37)$ & $(0.51)$ & $(0.33)$ \\
& -0.08 & -0.34 & -0.18 & 0.12 \\
& $(0.11)$ & $(0.25)$ & $(0.17)$ & $(0.14)$ \\
& 0.63 & 3.26 & 0.34 & 0.23 \\
& $(0.79)$ & $(1.98)$ & $(3.56)$ & $(0.95)$ \\
& $2.14 * * *$ & 1.35 & 1.01 & $2.56 * * *$ \\
& $(0.65)$ & $(2.02)$ & $(3.47)$ & $(0.73)$ \\
& & & & \\
& 249 & 79 & 82 & 100 \\
& 0.08 & 0.29 & 0.27 & 0.17 \\
\hline
\end{tabular}

Each model is estimated using OLS. Robust standard errors clustered on sub-location (233 clusters) are reported in parantheses. The interaction between the treatment indicator and each variables provides an estimate of that covariate's impact on the likelihood that vote buying is effective. The models also include the main independent variables without the interaction term. 


\section{Results on Vote Buying Prevalence}

Table D.1: The Distribution of List Experiment Respones in Treatment and Control Groups

\begin{tabular}{lcc|cc|cc} 
& \multicolumn{2}{c}{ Control Group } & \multicolumn{2}{c}{ Effectiveness Treatment Group } & \multicolumn{2}{c}{ Prevalence Treatment Group } \\
\hline Response & Frequency & Percentage & Frequency & Percentage & Frequency & Percentage \\
\hline 0 & 0 & $0 \%$ & 0 & $0 \%$ & 0 & $0 \%$ \\
1 & 290 & $47 \%$ & 215 & $38 \%$ & 235 & $36 \%$ \\
2 & 235 & $38 \%$ & 204 & $36 \%$ & 280 & $43 \%$ \\
3 & 72 & $12 \%$ & 113 & $20 \%$ & 96 & $15 \%$ \\
4 & 25 & $4 \%$ & 29 & $5 \%$ & 30 & $4 \%$ \\
5 & 0 & $0 \%$ & 8 & $1 \%$ & 12 & $2 \%$ \\
\hline Total & 62 & & 569 & & 653 & \\
\hline
\end{tabular}


Table D.2: Balance Tests, Vote Buying Offers LE

\begin{tabular}{lcccc}
\hline \hline & Mean Control & Mean Treatment & Difference & P-Value \\
\hline Male & 0.466 & 0.484 & -0.018 & 0.536 \\
Age & 2.418 & 2.483 & -0.065 & 0.309 \\
Rural Sub-Location & 0.623 & 0.633 & -0.010 & 0.727 \\
Share in Sub-Location with Radio Service & 0.721 & 0.708 & 0.013 & 0.184 \\
Population Density (log) & 6.062 & 5.946 & 0.116 & 0.251 \\
Share in Sub-Location with Electricity & 0.224 & 0.216 & 0.007 & 0.664 \\
Share in Sub-Location with Piped Water & 0.197 & 0.192 & 0.005 & 0.723 \\
Share with Primary Education & 0.490 & 0.480 & 0.010 & 0.226 \\
Share with Secondary Education & 0.185 & 0.182 & 0.003 & 0.610 \\
Sub-Location Unemployment Rate & 0.463 & 0.448 & 0.016 & 0.058 \\
Ethno-Linguistic Fractionalization (district) & 0.432 & 0.443 & -0.011 & 0.572 \\
Vote Margin (top two candidates) & 0.257 & 0.255 & 0.002 & 0.882 \\
\hline \hline
\end{tabular}


Table D.3: List Experiment Results, Vote Buying Offers LE

\begin{tabular}{|l|c|c|c|c|c|}
\hline & MeanControl & MeanTreatment & ListEstimate & p-value & DirectEstimate \\
\hline Full & 1.73 & 1.93 & .2 & 0 & .23 \\
\hline HighRadio & 1.72 & 1.89 & .17 & .01 & .23 \\
\hline LowRadio & 1.74 & 2 & .25 & 0 & .23 \\
\hline HighCompetition & 1.76 & 1.97 & .21 & .01 & .24 \\
\hline MedCompetition & 1.73 & 1.95 & .22 & .01 & .22 \\
\hline LowCompetition & 1.69 & 1.88 & .19 & .04 & .24 \\
\hline HighElectricity & 1.73 & 1.9 & .17 & .01 & .22 \\
\hline LowElectricity & 1.72 & 1.97 & .24 & 0 & .25 \\
\hline HighPrimaryEd & 1.7 & 1.95 & .25 & 0 & .25 \\
\hline LowPrimaryEd & 1.76 & 1.91 & .16 & .02 & .21 \\
\hline HighSecondaryEd & 1.73 & 1.93 & .2 & 0 & .23 \\
\hline LowSecondaryEd & 1.73 & 1.94 & .2 & 0 & .23 \\
\hline HighUnemployment & 1.73 & 1.92 & .19 & .01 & .21 \\
\hline LowUnemployment & 1.73 & 1.94 & .21 & 0 & .26 \\
\hline Urban & 1.72 & 1.88 & .16 & .03 & .2 \\
\hline Rural & 1.74 & 1.96 & .23 & 0 & .25 \\
\hline Men & 1.55 & 1.72 & .17 & .01 & .19 \\
\hline Women & 1.89 & 2.14 & .25 & 0 & .27 \\
\hline
\end{tabular}

The first two columns present the mean response to the list experiment question in treatment and control. The LE estimate is the difference of means and the p-value is from a difference of means test. The final column presents the direct question estimate. 
Table D.4: Multivariate Analysis of the List Experiment Vote-Buying Offer Models

\begin{tabular}{lcccc}
\hline & $(1)$ & $(2)$ & $(3)$ & $(4)$ \\
VARIABLES & All & $\begin{array}{c}\text { High } \\
\text { Comp. }\end{array}$ & $\begin{array}{c}\text { Med. } \\
\text { Comp. }\end{array}$ & $\begin{array}{c}\text { Low } \\
\text { Comp. }\end{array}$ \\
\hline \multirow{2}{*}{ Treatment x Radio Service (continuous) } & -0.33 & 0.30 & -1.18 & -0.11 \\
Treatment x Electoral Competition & $(0.56)$ & $(1.00)$ & $(1.03)$ & $(0.81)$ \\
Treatment x Share with Primary Education & -0.04 & & & \\
Treatment x Electricity & $(0.21)$ & & & \\
Treatment x Unemployed & -0.38 & -0.93 & -0.16 & -0.43 \\
Treatment x Population Density (log) & $(0.79)$ & $(1.24)$ & $(1.28)$ & $(0.92)$ \\
Treatment x Rural & -0.16 & -0.27 & -0.89 & 0.36 \\
Treatment x Male & $(0.41)$ & $(0.62)$ & $(0.69)$ & $(0.50)$ \\
Treatment x Age & -0.48 & -0.83 & 0.31 & -0.05 \\
Treatment & $(0.37)$ & $(0.77)$ & $(0.60)$ & $(0.80)$ \\
Constant & $0.10 * *$ & 0.12 & $0.17 * *$ & 0.07 \\
R-squared & $(0.05)$ & $(0.09)$ & $(0.07)$ & $(0.07)$ \\
& 0.12 & 0.41 & -0.37 & $0.44 *$ \\
& $(0.17)$ & $(0.26)$ & $(0.23)$ & $(0.23)$ \\
& -0.15 & -0.30 & -0.01 & -0.04 \\
& $(0.10)$ & $(0.19)$ & $(0.14)$ & $(0.15)$ \\
& 0.03 & -0.06 & $0.15 * *$ & -0.07 \\
& $(0.05)$ & $(0.10)$ & $(0.07)$ & $(0.09)$ \\
& 0.17 & 0.17 & 0.15 & -0.04 \\
& $(0.38)$ & $(0.89)$ & $(0.49)$ & $(0.51)$ \\
& $1.89 * * *$ & $2.21 * *$ & $1.91 * * *$ & $2.16 * * *$ \\
& $(0.32)$ & $(0.97)$ & $(0.39)$ & $(0.36)$ \\
& & & & \\
Tbservations & 1,142 & 385 & 365 & 485 \\
& 0.09 & 0.14 & 0.17 & 0.09 \\
\hline
\end{tabular}

Each model is estimated using OLS. Robust standard errors clustered on sub-location (233 clusters) are reported in parantheses. The interaction between the treatment indicator and each variables provides an estimate of that covariate's impact on the likelihood that the respondent was offered a good in exchange for their vote. The models also include the main independent variables without the interaction term. For ease of interpretation, they are omitted here. 